\title{
Pengembangan Media Shooting Bolabasket Untuk Siswa Sekolah Menengah Pertama
}

\author{
Imamul Wahid Tanjung, Rifqi Aufan, Hariadi \\ Fakultas Ilmu Keolahragaan, Universitas Negeri Medan \\ imamulhakim710@gmail.com,rifqiaufan87@unimed.ac.id, hariadi@unimed.ac.id
}

\begin{abstract}
Abstrak: Penelitian ini bertujuan untuk mengembangkan media alat bantu pembelajaran yang disesuaikan dengan permasalahan yang dihadapi dalam pembelajaran shooting bolabasket di tingkat sekolah menengah pertama. Metode yang digunakan dalam penelitian ini adalah penelitian dan pengembangan $(\mathrm{R} \& \mathrm{D})$ yang bertujuan menghasilkan produk berupa media pembelajaran target ring untuk mata pelajaran penjasorkes yang mempelajari materi shooting dalam permainan bolabasket. Pada penelitian ini, data mengenai kualitas produk pembelajaran target ring yang dihasilkan diperoleh dengan bantuan angket penelitian yang terdiri dari dua aspek, yaitu aspek kualitas media dan aspek kualitas materi. Agar diperoleh media pembelajaran target ring yang berkualitas tinggi, maka dalam proses pembuatannya dilakukan beberapa tahapan, diantaranya yaitu uji validasi kualitas alat oleh ahli alat, uji validasi kualitas materi oleh ahli materi, uji coba dengan siswa satu lawan satu, uji coba dengan siswa kelompok kecil, uji coba dengan siswa kelompok besar. Hasil penelitian ini sebuah produk alat pembelajaran target ring dengan kualitas yang "baik". Hal tersebut dibuktikan dengan diperolehnya hasil uji coba produk oleh subjek dengan rerata skor 53\% yang termasuk dalam, sedangkan hasil validasi ahli dengan rerata skor 53,33\% yang termasuk dalam ketegori "cukup baik", dan diperolehnya hasil uji coba pemakaian oleh subjek dengan rerata skor $81,67 \%$, sedangkan hasil validasi ahli dengan rerata skor $85,33 \%$ yang termasuk dalam kategori sangat baik.
\end{abstract}

Kata Kunci: Media Pembelajaran, Shooting

\section{The Development of Shooting Media in Basketball for Junior High School Students}

\begin{abstract}
This study aims to 1) Identify and analyze the problems faced by teachers and students in implementing Basketball Shooting Learning Activities; 2) Development of learning aids media that are adjusted to the problems encountered in basketball shooting learning; 3) Making media for learning tools Shooting basketball that is tailored to the problems faced in learning; The method used in this research is research and development $(R \& D)$ which aims to produce a product in the form of target ring learning media for Physical Education subjects who study Shooting material in basketball games. In order to obtain high quality target ring learning media, the manufacturing process is carried out in several stages, including the validation of the quality of the tool by the tool expert, the validation of the quality of the material by the material expert, testing with students one on one, testing with small group students, trials with large group students. The results of this study are a product of target ring learning tools with "good" quality. This is evidenced by obtaining the results of product trials by subjects with an average score of 53\% included in, while the results of expert validation with a mean score of 53.33\% included in the category are "quite good", and the results obtained by the subjects using the subjects with a mean a score of $81.67 \%$, while the results of expert validation with an average score of $85.33 \%$ are included in the "very good" category.
\end{abstract}

Keywords: Learning media, Shooting

\section{PENDAHULUAN}

Pendidikan jasmani olahraga dan kesehatan merupakan salah satu mata pelajaran yang terdapat dalam kurikulum SMP (Sekolah Menengah Pertama) yang harus diajarkan kepada siswa, salah satu 
pembelajaran shooting dalam permainan bolabasket. Olahraga bolabasket adalah salah satu bagian dari cabang olahraga yang harus dikuasai oleh siswa, oleh karena itu hamper setiap sekolah diajarkan permainan bolabasket. Karena sekolah merupakan sarana yang paling potensi untuk melakukan pembinaan olahraga bolabasket pada usia dini. Untuk mencapai pembinaan bakat diusia dini dalam olahraga bolabasket dibutuhkan juga guru yang handal didalam menyajikan materi pembelajaran.

Penyajian materi pelajaran yang ada terbatas pada gaya mengajar demonstrasi dan komando, Hal itu mengakibatkan siswa berpusat pada apa yang disampaikan oleh guru. Sementara pola pikir dan keadaan terutama pada saat sekarang ini dimana siswa dituntut lebih aktif dari guru dalam proses pembelajaran serta mengambil suatu tindakan.

Berkaitan dengan hal tersebut desain media pembelajaran seorang guru dapat menentukan gaya mengajar apa yang dilaksanakan serta dapat memberikan perubahan pada diri dan keterampilan siswa kearah yang ingin dicapai. Media dapat menjadi salah satu faktor penentu keberhasilan pembelajaran, melalui media proses pembelajaran bisa lebih menarik dan menyenangkan (Joyfull Learning). Penggunaan media pengajaran dapat mempertinggi kualitas proses belajar mengajar yang pada akhirnya diharapkan dapat meningkatkan kualitas hasil belajar para siswa.

Dalam permasalahan yang ada pada saat melakukan shooting pembelajaran bolabasket siswa SMP kurang sesuai dalam melakukang shooting pembelajaran bolabasket dengan ketingian ring bolabasket standar, oleh karena itu saya mengembangkan sebuah alat untuk melakukan shooting dalam permainan bolabasket dengan kriteria yang disesuai dengan tingkat karakteristik siswa SMP, yang membuat modifikasi alat ring basket yang bisa disesuaikan tinggi rendahnya postur tubuh siswa dan kemampuan seorang siswa dalam melakukan shooting.

Penelitian pengembangan menurut Dwiyono (2004:3) adalah penelitian yang berorientasi untuk menghasilkan atau mengembangkan produk, misalnya mengembangkan model sekolah olahraga, mengembangkan kurikulum pendidikan jasmani, mengembangkan strategi/metode pembelajaan olahraga, mengembangkan media pembelajaran olahraga, mengembangkan buku teks pembelajaran olahraga. Proses penelitian pengembangan bersifat melingkar atau berpilin mulai dari aktivitas analisa, merancang, mengevaluasi dan merevisi sampai tujuan yang diinginkan.

Media pendidikan digunakan dalam rangka komunikasi dan interaksi guru dan siswa dalam proses pembelajaran. Dengan menggunakan media pembelajaran diharapkan siswa dapat memperoleh berbagai pengalaman nyata, sehingga materi pembelajaran yang disampaikan dapat diserap dengan mudah dan lebih baik. Proses belajar mengajar sering ditandai dengan adanya unsur tujuan, bahan, metode dan alat, serta evaluasi. Metode dan media merupakan unsur yang tidak dapat dipisahkan dari unsur pembelajaran yang lain.

Di dalam proses pembelajaran media berguna sebagai penyaji stimulus (informasi, sikap dan lain-lain), meningkatkan keserasian dalam penerimaan informasi. Dalam hal-hal tertentu media juga berguna untuk mengatur langkah-langkah kemajuan, serta memberikan umpan balik. Hamalik (1982: 30) mengungkapkan bahwa: "pemakaian media pembelajaran dalam proses belajar mengajar dapat membangkitkan motivasi dan rangsangan kegiatan belajar dan bahkan membawa pengaruh-pengaruh psikologis terhadap siswa. Penggunaan media pembelajaran pada tahap orientasi pembelajaran akan sangat membantu keefektifan proses pembelajaran dan penyampaian pesan danisi pelajaran saat itu.

Bolabasket adalah suatu permainan yang bertujuan untuk mencari nilai/angka sebanyakbanyaknya dengan cara memasukkan bola ke basket (keranjang) lawan dan mencegah lawan untuk mendapat nilai. Saat memainkan bola, pemain dapat mendorong bola, memukul bola dengan telapak tangan terbuka, melemparkan bola, atau shooting ke segala penjuru dalam lapangan permainan (muhajir, 2007:39).

Menembak (shooting) merupakan satu teknik yang cukup penting dalam upaya mencapai kemenangan. Menembak merupakan suatu keterampilan tersebut diperlukan latihan yang terusmenerus. Latihan menembak harus direncanakan secara sistematis sehingga setiap pemain akan mempratekkan jenis tembakan yang paling disukainya, latihan ini harus meliputi semua jenis tembakan dari posisi yang berbeda dan dalam pola yang disukai. Kalau pemain hendak memenangkan pertandingan maka mereka harus memiliki kemampuan shooting yang baik.

Ishak dan Rusdi (2009:33) dalam bukunya mengemukakan bahwa teknik shooting meliputi: 1) Balance: shooting yang baik bermula dari posisi kaki yang siap (triple threat position); 2) Target: ring 
adalah target shooting, maka fokus pandangan kita adalah ring; 3) Shooting hand: cengkram bola dengan baik dan lebarkan jari-jari, kecuali telapak tangan tidak menyentuh bola. Tekukkan pergelangan tangan melebihi 70 derajat. Kunci siku pada posisi L. kesalahan yang sering terjadi karena siku sebagai penopang terbuka ke samping; 4) Balance hand: tangan pendukung ini hanya digunakan untuk menjaga keseimbangan memegang bola sebelum meninggalkan tangan. Kesalahan terjadi saat mencengkram bola, dimana ibu jari ikut mendorong pada saat shooting; 5) Release: teori ini mengajarkan bagaimana melepas bola dengan back spin (putaran bola kebelakang). Hindari kebiasaan tidak melihat target dan hanya fokus melihat bola. Agar bola dapat back spin gunakan jarijari untuk menekan bola keatas, sesaat sebelum bola dilepaskan; dan 6) Follow through: langkah terakhir shooting yang baik adalah pergerakan tangan dengan mengikuti ke arah ring. Siku tetap dikunci dan gunakan tenaga dorongan terakhir dari pergelangan tangan.

Media pembelajaran adalah suatu alat yang membantu siswa supaya terjadi proses pembelajaran. Menurut Arsyad (2004: 7), media pembelajaran memiliki pengertian alat bantu pada proses belajar baik didalam maupun di luar kelas. Sedangkan dalam Peraturan Menteri Pendidikan Nasional Republik Indonesia nomor 24 tahun 2007, yang dimaksud media pembelajaran adalah peralatan pendidikan yang digunakan untuk membantu komunikasi dalam pembelajaran.

Jenis-jenis media menurut Bretz (Toto, 2008:14) mengidentifikasi ciri utama media menjadi tiga unsur pokok, yaitu suara, visual dan gerak. Visual dibedakan menjadi tiga yaitu gambar, garis dan simbol yang merupakan suatu kontinum dari bentuk yang ditangkap dengan indera penglihat. Berdasarkan uraian diatas dapat disimpulkan bahwa media pembelajaran adalah segala sesuatu yang dapat mengantar pesan atau materi pembelajaran dari guru ke siswa yang dapat merangsang pikiran, perhatian dan minat belajar siswa sehingga proses pembelajaran dapat berlangsung secara efektif.

Adapun sarana yang ada digunakan selama ini berupa sasaran shooting menggunakan ban motor yang di modifikasi dan dinding untuk latihan shooting dan passing. Sementara itu media alat shooting yang dikembangkan oleh peneliti bertujuan untuk memaksismalkan penggunaan bola dan waktu dengan seefesien mungkin, sehingga memberikan kesempatan bagi pemain untuk dapat melakukan shooting dengan lebih banyak dan terarah pada sasaran yang dituju. Berikut adalah gambar media alat yang dikembangkan oleh peneliti:

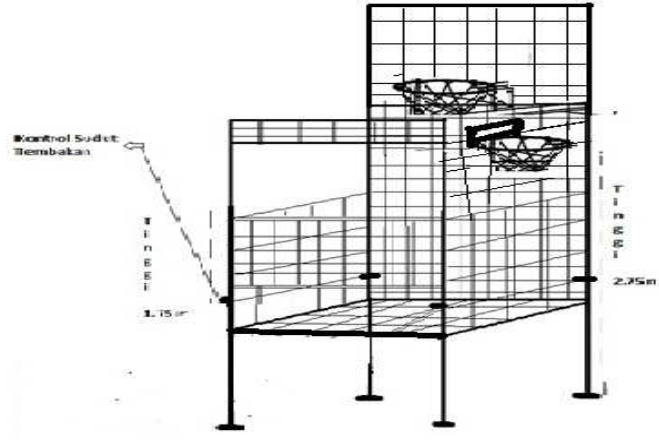

Gambar 1. Desain Pengembangan Media Shooting Bolabasket

\section{METODE}

Tujuan penelitian ini adalah untuk menghasilkan produk berupa media pembelajaran shooting bolabasket untuk siswa SMP. Adapun metode yang digunakan dalam penelitian ini menggunakan penelitian pengembangan. Penelitian dalam model pembelajajaran ini menggunakan pendekatan kuantitatif serta menggunakan model pengembangan Research \& Development ( $\mathrm{R}$ \& $\mathrm{D})$ dari sugiyono.

Metode Reasearch and Development (R \& D) (sugiyono hal :298). Adapun langkah-langkah pada desain di atas antara lain:

1. Pertama kali yang ditentukan adalah potensi dan masalah yang akan dijadikan landasan awal pada proses pengembangan. Masalah yang ditemukan selain hasil belajar siswa yang rendah, yaitu kurang efektif dan refesiensinya pembelajaran shooting dalam proses mengajar. Terdapat 
beberapa faktor penyebabnya antara lain, jam pelajaran yang minim, sarana dan prasarana yang tidak sebanding dengan jumlah siswa dengan tingkat kemampuan motorik siswa yang rendah.

2. Pengumpulan data yaitu dengan mengumpulkan informasi sebagai landasan dalam pengembangan media pembelajaran. Dalam hal ini adalah hasil belajar shooting siswa dan kuisioner.

3. Desain produk yaitu pembuatan media alat drill shooting (rancangan produk) di dibuat untuk memenuhi kebutuhan kompetensi siswa.

4. Validasi desain, diskusi dilakukan oleh ahli yang bersangkutan sesuai dengan apa yang akan dikembangkan sebelum diujicobakan.

5. Revisi Desain, sebelum diujicobakan, draft d esain media terlebih dahulu harus di nilai dan direvisi oleh pakar ahli untuk dilakukan penyesuaian.

6. Uji coba produk I kelompok kecil, dilakukan dengan mengujicobakan media yang telahdibuatdalam pembelajaran di lapangan.

7. Revisi Produck, setelah diujibakan, produk direvisi sesuai dengan penilaian para ahli dan kuisioner dari subjek penelitian dalam hal ini siswa.

8. Uji coba produk II kelompok besar, hasil dari revisi pengujian kelompok kecil, kemudian dilanjutkan dilakukan dengan mengujicobakan media yang telah direvisi dalam uji kelompok dengan skala lebih besar.

9. Revisi produk kedua kelompok besar, setelah diujibakan, produk direvisi sesuai dengan penilaian para ahli dan kuisioner dari subjek penelitian dalam hal ini siswa didukung dengan penilaian hasil belajar shooting siswa dalam pembelajaran bolabasket.

10. Produksi masal, penyempurnaan produk untuk menuju produk akhir yang diharapkan pada pengembangan ini adalah media alat drill shooting yang diharapkan dapat memberikan manfaat dalam bidang pendidikan dan ilmu kepalatihan.

11. Data yang digunakan pada model pengembangan media pembelajaran pada siswa adalah data kualitatif, karena dinyatakan dengan kalimat dan bukan angka, sedangkan data kuantitatifnya diperoleh dengan cara mengkonversi data kualitatif dengan jalan memberika skor pada data yang telah dikumpulkan.

12. Instrumen yang digunakan dalam penelitian ini adalah dengan menggunakan angket untuk analisis kebutuhan, kuesioner evaluasi ahli desain rancang bangunan dan ahli media pembelajaran penjas dan olahraga. Instrumen uji lapangan awal berupa tes kemampuan shooting dan kuisioner disusun berdasarkan konsep evaluasi dari para siswa.

Data yang digunakan pada penelitian ini adalah data kualitatif, karena dinyatakan dengan kalimat dan bukan angka, sedangkan data kuantitatifnya diperoleh dengan cara mengkonversi data kualitatif dengan jalan memberikan skor pada data yang telah dikumpulkan.

\section{HASIL DAN PEMBAHASAN}

Produk awal yang dihasilkan dalam penelitian ini adalah media pembelajaran berupa target ring. Media pembelajaran ini merupakan hasil modifikasi dari ring basket untuk membantu siswa melakukan teknik set shoot dalam permainan bolabasket. Didalam media pembelajaran ini, ring digunakan sebagai target atau sasaran agar proses pembelajaran teknik set shoot dalam bolabasket dapat menjadi lebih menarik. Media pembelajaran terget ring ini dikembangkan melalui berbagai tahapan, diantaranya yaitu: pendahuluan, pengembangan, dan uji validitas kualitas produk. 


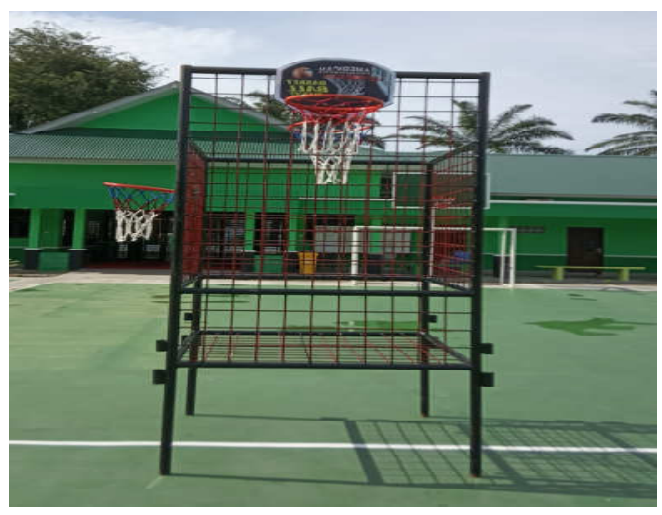

Gambar 2. Produk Media Shooting Bolabasket Hasil Pengembangan

Secara garis besar terdapat tiga tujuan dari dilakukannya analisis kebutuhan yaitu: (1) Memberikan informasi seberapa jauh pembelajaran khususnya pada materi set shoot bolabasket sejalan dengan tujuan atau sesuai dengan karakteristik kukrikulum yang telah dirumuskan. (2) Seberapa penting adanya pengembangan media pembelajaran set shoot bolabasket dengan menggunakan variasi pembelajaran yang disesuaikan dengan gerak yang dilakukan, guna tercapainya proses pembelajaran yang efektif, efesien dan menarik. (3) Menganalisis untuk mendapatkan solusi dari kendala yang di jumpai dilapangan serta memberdayakan potensi yang mendukung pengembangan pembelajaran dilapangan.

Dari analisis kelompok kecil yang telah dilakukan terhadap 15 siswa dapat disimpulkan, 73\% mampu menggunakan media shooting dan $27 \%$ belum mampu di kembangkan dalam melakukan shooting , $73 \%$ berpendapat pengembangan media shooting sudah tepat dikembangkan dan $27 \%$ berpendapat media tersebut belum cocok dikembangakan dalam shooting bolabasket tersebut.

\section{Uji Coba Kelompok Kecil}

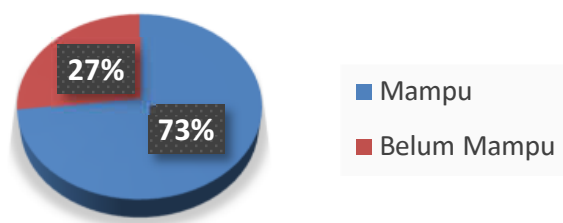

\section{Gambar 3. Persentase Hasil Uji Coba Kelompok Kecil}

Dari analisis kebutuhan uji kelompok besar yang telah dilakukan terhadap 30 siswa dapat disimpulkan, 100\% mampu melakukan shooting bolabasket dalam pengembangan media shooting. $70 \%$ berpendapat pengembangan media sudah tepat digunakan dan $30 \%$ berpendapat pengembangan media shooting tidak cocok digunakan dalam shooting bolabasket tersebut pada pertandingan sudah cukup dan sesuai.

Pada tahap ini ada 15 siswa yang melakukan uji coba kelompok kecil dengan melakukan set shoot shooting bolabasket. Setelah melakukan uji coba maka siswa diberikan instrumen penilaian dan evaluasi untuk menilai pengembangan media shooting tersebut. Nilai persentase validasi uji coba oleh siswa adalah sebesar $53 \%$.

Jadi nilai rata-rata persentase validasi desain produk oleh ahli pada uji kelompok kecil adalah sebesar 53,33\%. Berdasarkan keterangan dalam gambar penilaian persentase validasi ahli Sudjana (2005 : 46-47) maka nilai rata-rata validasi berada pada rentang nilai 47\% - 64\% maka dapat disimpulkan bahwa desain pada uji kelompok kecil pengembangan media shooting bolabasket ini dikategorikan cukup baik dan kurang valid untuk digunakan pada tahap uji coba setelah perbaikan. 
Pada tahap ujicoba pemakaian ada 30 siswa yang melakukan uji coba kelompok besar terhadap pengembangan media shooting bolabasket. Setelah melakukan uji coba maka siswa diberikan instrument penilaian dan evaluasi untuk menilai pengembangan media tersebut. Nilai persentase validasi uji coba kelompok besar adalah $81,67 \%$.

Jadi nilai rata-rata persentase validasi desain produk oleh ahli pada uji kelompok besar adalah sebesar $85,33 \%$. Berdasarkan keterangan dalam table penilaian persentase validasi ahli Sudjana (2005: 46-47) maka nilai rata-rata validasi berada pada rentang nilai $83 \%$ - 100\% maka dapat disimpulkan bahwa desain pada uji kelompok besar pengembangan media shooting bolabasket ini dikategorikan sangat baik dan valid untuk digunakan tanpa perbaikan.

\section{Uji Coba Produk}

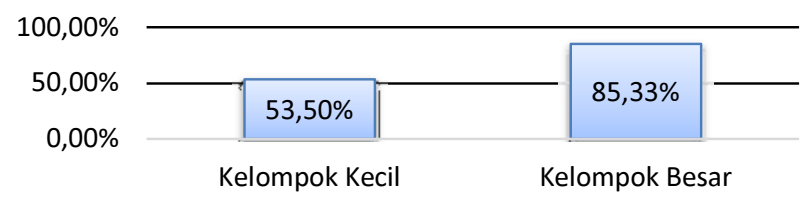

Gambar 4. Persentase Hasil Ujicoba Produk

Berdasarkan analisis data pada uji validasi poduk media pembelajaran target ring, dapat diketahui bahwa produk media pembelajaran target ring termasuk dalam kriteria sangat baik. Penilaian tahap awal yaitu validasi ahli media, menyatakan bahwa validitas produk media pembelajaran target ring dari aspek media termasuk kriteria baik setelah dilakukan perbaikan. Berdasarkan saran-saran pada tahap awal, akhirnya dihasilkan produk media pembelajaran target ring dengan nilai sangat baik oleh validator ahli media.

Begitu juga pada uji validasi kualitas produk media pembelajaran target ring dari aspek materi. Penilaian tahap awal pada validasi ahli materi, menyatakan bahwa kualitas produk materi pembelajaran target ring dari aspek materi termasuk kriteria baik, setelah dilakukan perbaikan berdasarkan saran-saran pada tahap awal, akhirnya dihasilkan produk materi pembelajaran target ring dengan nilai sangat baik oleh validator ahli materi.

Hasil produk media pembelajaran target ring dari media materi di nilai sangat baik, karena dari segi materi produk alat pembelajaran target ring sudah melalui prosedur yang tepat yaitu dari sumber baik diktat dari dosen pengampu maupun buku-buku pendukung mata kuliah tes, pengukuran dan evaluasi pembelajaran penjasorkes. Sedangkan ahli media juga menilai sangat baik, artinya secara penampilan (wujud) dari produk yang dihasilkan sudah menemiliki fungsi sebagai media pembelajaran target ring, seperti yang dijelaskan dalam Agus S. Suryobroto (2004: 16), mengenai media pembelajaranyang baik harus memenuhi syarat: 1) Dengan membuat kaki (alas) yang berbentuk tripod maka alat tersebut tidak akan mudah roboh. Mur (baut) yang sudah dibuat lebih aman; 2) Karena bahan yang dipakai dari besi bekas yang cukup murah dan memiliki daya tahan yang lama sehinga tidak mudah rusak serta ramah lingkungan; dan 3) Bentuk serta warna yang menarik, ketinggian alat ini dapat diatur sesuai keinginan dengan memindahkan engsel yang terdapat pada media. Diharapkan dapat membantu siswa dalam memahami teknik-teknik shooting yang benar dan berbagai macam variasi permainan yang dapat dilakukan.

\section{SIMPULAN}

Data yang diperoleh berdasarkan dari hasil uji coba kelompok kecil, uji coba kelompok besar, uji lapangan serta pembahasan hasil penelitian, maka dapat diambil kesimpulan bahwa: 1) Pengembangan media pembelajaran shooting bolabasket dinyatakan valit dan dapat digunakan oleh para ahli; 2) Pengembangan media pembelajaran shooting bolabasket membantu guru di dalam pelaksanaan proses pembelajaran secara efektif dan efesien; dan 3) Melalui pengembangan media pembelajaran shooting bolabasket yang diberikan dapat memberikan peningkatan hasil belajar shooting siswa SMP. 
Sehubungan dengan media yang dikembangkan, peneliti mengemukakan saran guna kesempurnaan penggunaan pada pengembangan media shooting bolabasket, maka dapat disarankan sebagai berikut: 1) Produk yang dikembangkan ini dapat dijadikan sebagai contoh pengembangan media pembelajaran shooting bolabasket dalam proses pembelajaran pendidikan jasmani, yang mempelajari materi teknik shooting permainan bolabasket; 2) Perlunya penelitian dan pengembangan lebih lanjut untuk mengetahui tingkat efektifitas dalam penggunaan alat pembelajaran target ring, yang mempelajarai materik tekni shooting olahraga bolabasket; dan 3) Perlunya pengembangan produk sehingga dihasilkan alat pembelaajaran target ring dengaan kualitas alat dan materi yang lebih baik lagi.

\section{DAFTAR PUSTAKA}

Asim. 2007. Langkah-langkah Penelitian Pengembangan.Alih bahasa: Dian Ruslaini. Jakarta: PT Grafindo Persada,

Federation Internationale de Volley Ball. 1989. Coaches Manual 1. FIVB, Lausanna (CH)

Gay, L.R. (1991). Educational Evaluation and Measurement: Com-petencies for Analysis and Application. Second edition. New York: Macmillan Publishing Compan.

Jon Oliver. 2007. Dasar-dasar Bolabasket. Bandung: Pakar raya.

Keven.A. 2007. Permainan Bolabasket. Yogyakarta, PT. Citra Aji Parama.

Margono A. 2010. Permainan Bolabasket. Surakarta: Sebelas Maret University Press.

Punaji Setyosari. 2010. Metode Penelitian Pendidikan dan Pengembangan. Jakarta: Prenada Media Group.

Nana Sudjana. 1991. Strategi Belajar Mengajar. Jakarta: Rineka Cipta.

Nusa Putra. 2011. Research \& Development Divisi Buku Perguruan Tinggi. Jakarta: PT. Raja Grafindo Persada.

Sadiman, Arif. 2003. S Media Pendidikan Pengertian, Pengembangan, dan Pemanfaatan. Jakarta: Pustekom Dikbud.

Subroto. Toto. 2000. Pemantapan Kemampuan Mengajar (PKM). Departemen Pendidikan dan Kebudayaan.

Sudjan. 1990. Penilaian Hasil Proses Belajar Mengajar. Bandung: Rosdakarya.

Sugiyono. 2011. Metode Penelitian Kuantitatif, Kualitatif, dan $R \&$ D. Bandung: Alfabeta.

Wissel, Hall. 1999. Bolabasket. Jakarta: PT. Raja Grafindo Persada. 